\title{
IDENTIFICATION OF WATER TURBIDITY WITH TURBIDITY SENSOR BASED ON ARDUINO
}

\author{
Hafdiarsya Saiyar' ${ }^{1}$, Mohammad Noviansyah² \\ Program Studi Teknologi Komputer1, Program Studi Sistem Informasi² \\ Universitas Bina Sarana Informatika \\ hafdiarsya.hyr@bsi.ac.id¹, mohammad.mnh@bsi.ac.id² \\ $\left.{ }^{*}\right)$ Corresponding Author
}

\begin{abstract}
Abstrak
Air merupakan kebutuhan yang penting bagi semua makhluk hidup, terutama manusia. Manusia membutuhkan air dengan kualitas yang memenuhi persyaratan fisik, mikrobiologi, kimia, dan radiologi yang terdapat dalam parameter wajib dan parameter tambahan. Pemilihan parameter tersebut sangat penting untuk memenuhi persyaratan air yang baik, yaitu tidak berasa, tidak berbau, dan berwarna. Sedangkan parameter yang digunakan untuk pengidentifikasian air ada tiga,yakni parameter $\mathrm{pH}$, tingkat kekeruhan, dan parameter suhu. Dari permasalahan tersebut penulis meneliti pendeteksian kualitas air, khususnya tentang kekeruhan air. Penulis mencoba membuat suatu alat yang mampu mendeteksi tingkat kekeruhan air dengan turbidity sensor sebagai pendeteksi tingkat kekeruhan air, Arduino Uno sebagai pemroses hasil data yang telah dideteksi, dan LCD 16x2 sebagai penampil hasil pengukuran tingkat kekeruhan yang berupa nilai kekeruhan dan keterangan air yang diujikan. Rentang pengukuran yang dapat dideteksi oleh alat ini yaitu dari 0 - 3000 NTU. Metode penelitian yang digunakan adalah observasi langsung terhadap objek yang terpilih yaitu dilingkungan rumah penulis serta melakukan studi pustaka yang berkaitan dengan mikrokontroler Arduino. Tujuan penelitian ini adalah Untuk mengetahui dan mendeteksi tingkat kualitas air yang ada di masyarakat. Sebagai salah satu tools atau alternatif bagi masyarakat untuk mengetahui atau mendeteksi tingkat kualitas air secara dini.
\end{abstract}

Kata kunci: Arduino Uno, Kekeruhan air, LCD, NTU, Turbidity Sensor

\begin{abstract}
Water is an important need for all living things, especially humans. Humans need water with quality that meets the physical, microbiological, chemical, and radiological requirements contained in the mandatory and additional parameters. The selection of these parameters is very important to meet the requirements of good water, namely tasteless, odorless, and colorless. Meanwhile, there are three parameters used for water identification, namely $\mathrm{pH}$ parameters, turbidity levels, and temperature parameters. From these problems, the authors examine the detection of water quality, especially water turbidity. The author tries to make a tool that can detect the level of turbidity of water with a turbidity sensor as a detector of the level of turbidity in the water, Arduino Uno as a processor for the data results that have been detected, and a 16x2 LCD as a display of turbidity level measurement results in the form of turbidity values and descriptions of the water being tested. The measurement range that can be detected by this tool is from $0-3000$ NTU. The research method used is direct observation of the selected object, namely the author's home environment, and conducting library research related to the Arduino microcontroller. The purpose of this study was to determine and detect the level of water quality in the community. As one of the tools or alternatives for the community to find out or detect the level of water quality early.
\end{abstract}

Keywords: Arduino Uno, Water turbidity, LCD, NTU, Turbidity Sensor

\section{INTRODUCTION}

Humans, animals, and plants both need water to grow and develop. However, it certainly requires water with each capacity. To continue to live and develop, humans always need water every day. However, it's not just water that humans need. The water that humans need has a certain standard or quality. Good water quality can be seen from various things depending on its use. The water needed for human drinking needs is different in quality from the water used for sanitation needs.

According to the Regulation of the Minister of Health Number 492/MENKES/PER/IV/2010 concerning drinking water that is safe for health is if it meets the physical, microbiological, chemical, 
and radioactive requirements contained in the mandatory and additional parameters. The selection of important parameters in this measurement to meet the requirements of good water, namely, tasteless, odorless, and colored. There are three types of parameters used for water identification, namely, $\mathrm{pH}$ parameters, turbidity level parameters, and temperature parameters. (Amani \& Prawiroredjo, 2016).

The level of turbidity in the water can raise concerns that in the water used some substances are harmful to the human body and cause disease (Sutrino, 2004). Turbidity is an optical property of a solution that causes light through it to be absorbed and refracted (Kadir, 2013). Turbidity is expressed in units of NTU (Nephelometric Turbidity Units) and measured using a standard measuring instrument, namely a turbidimeter (Joko, 2010). However, this tool is only owned by certain parties, so the development of various water turbidity measuring instruments is carried out by utilizing electronic circuits (Suliyani, Suciyati, Pauzi, \& Surtono, 2021). Water Turbidity is a measure that uses the effect of light as a basis for measuring the state of raw water on the NTU (Nephelometric Turbidity Unit) or JTU (Jackson Turbidity Unit) or FTU (Formazin Turbidity Unit) scale. Turbidity of water is expressed in units of turbidity, which is equivalent to $1 \mathrm{mg} /$ liter of SiO2. This turbidity is caused by the presence of mixed objects or colloidal objects in the water(Manaor, Efendi, \& Informatika, 2017)(Effendi, 2003). To make it easier to determine the level of water turbidity, the parameters used are NTU (Nephelometer Turbidity Unit) units. (Wardhana, 2004).

In this study, the author only discusses the second parameter, namely, the level of water turbidity. Water turbidity is a form of measurement of scattered light from the interaction of suspended and dissolved materials in water samples, this is used as an indicator of water quality. (Kautsar, Rizal Isnanto, \& Didik Widianto, 2015).

The purpose of this study was to determine and detect the level of water quality in the community. As a tool or alternative for the community to find out or detect the level of water quality early.

\section{RESEARCH METHODS}

In collecting data and information, the author uses several research methods, including:

1. Observation Method

The author makes direct observations of the selected object, namely in the author's home environment, where the author observes the types of water that exist in the community where the author lives.

\section{Literature Study}

Conducting library research to support all the collection of the required information. Information collection is done by looking for references related to the tools that the author will make. These references are obtained from books, journals, articles, and the internet.

\section{A. Block Diagram}

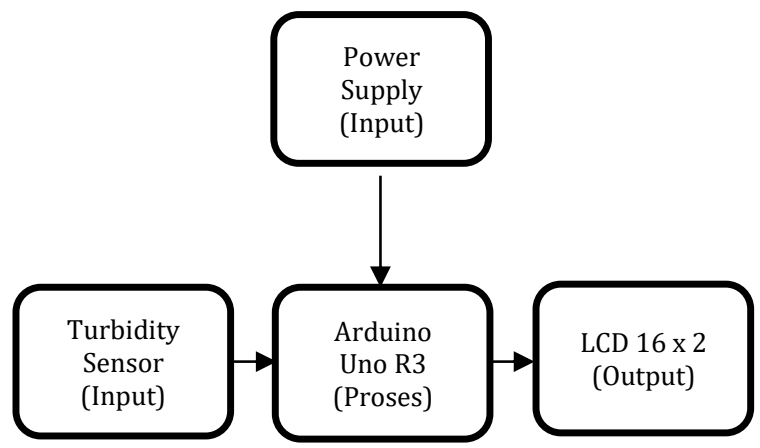

Picture 1. Block Diagram

The explanation of this tool circuit block is:

1. Input

This input component is the input component that will be processed. The input components consist of:

a. A power supply that supplies +12 volts to the appliance circuit

b. Turbidity Sensor which functions to detect the level of turbidity of water poses

\section{Process}

The process is an important component in a tool because it functions as a data manager that has been detected by the sensor which then the processed results will be displayed by the output. In this process, the author uses Arduino Uno R3.

3. Output

Output is the output of all processes that have been carried out. In this tool, the author uses a $16 \times 2$ LCD as the display output of the resulting process.

\section{A. Schematic of Tool Circuit}




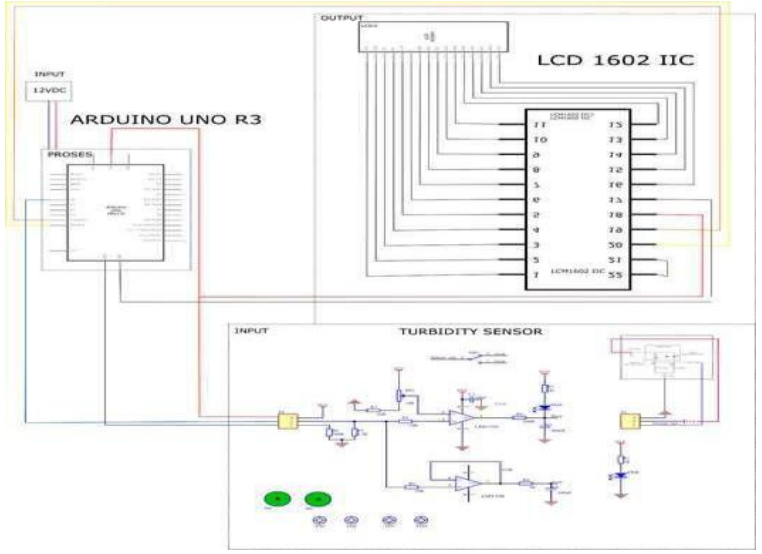

Picture 2. set of tools

The circuit schematic consists of a series of inputs, processes, and outputs. The input itself consists of a power supply obtained from a 12-volt adapter and a Turbidity Sensor which functions as a detector of turbidity in the water. The process in this tool is carried out by Arduino Uno. Arduino Uno processes and processes data that has been previously known by the Turbidity Sensor. Which then Arduino Uno displays the results to a $16 \mathrm{x} 2$ LCD. The output circuit consists of a $16 \times 2$ LCD which has been connected to I2C. The use of I2C is to simplify the pins that will be connected to the Arduino Uno. With I2C pins used in Arduino Uno only 4 pieces, namely the Ground pin, VCC, SDA, and SCL.

\section{B. How The Tool Work}

\section{Power Supply}

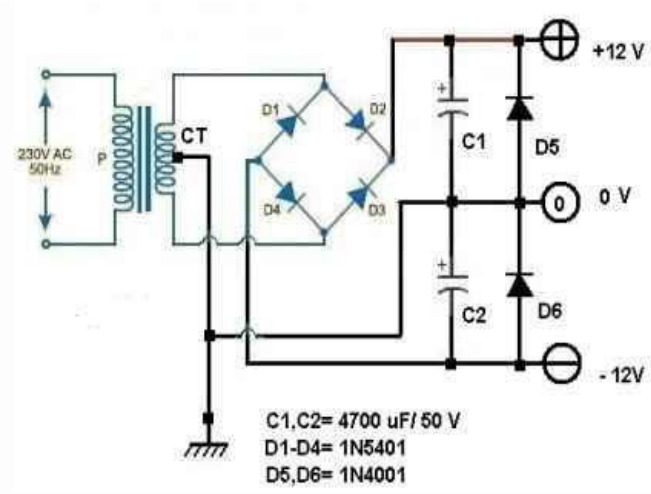

Picture 3 Power supply scheme

A power Supply is a pin that provides voltage for components or circuits that are connected to Arduino. (Galih, V., Purnomosari, E., 2019).

In this tool, the author uses a 12-volt power supply with a scheme like a picture above. This power supply uses a 12 Volt 1A CT stepdown type transformer, also uses a 1N5401 diode in the form of a bridge which functions as a full-wave rectifier. 2 capacitors function as voltage filters. And also use a $1 \mathrm{~N} 4001$ diode so that the output current is $1 \mathrm{~A}$.

\section{Turbidity Sensor}

Sensors are generally defined as devices capable of capturing physical (physical) or chemical phenomena and then converting them into electrical signals, either electric current or voltage. Physical phenomena that can stimulate sensors to produce electrical signals include temperature, pressure, force, magnetic field, light, and so on. (Suryono \& Pramusinto, 2016)

Turbidity sensor that can detect water turbidity by reading the optical properties of water due to light and as a comparison of light to be reflected with future light (Noor, Supriyanto, \& Rhomadhona, 2019). On the turbidity sensor, that the higher the level of water turbidity will be followed by a change in the sensor output voltage(Wadu, Ada, \& Panggalo, 2017).

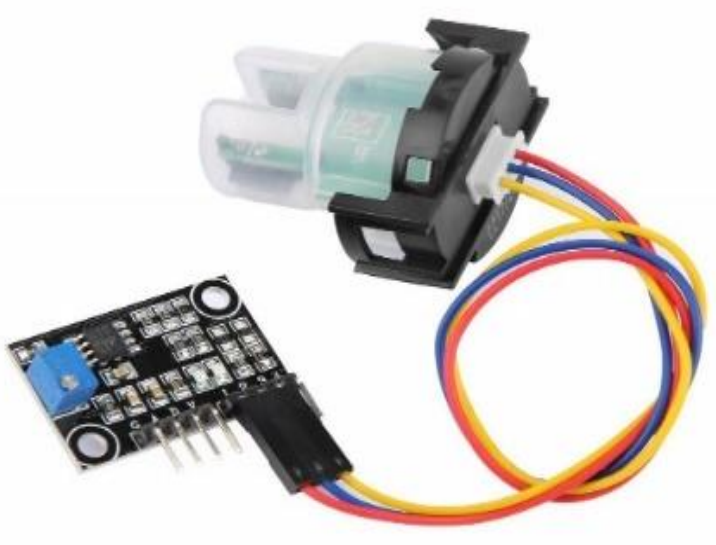

Picture 4 Turbidity Sensor

Turbidity Sensor consists of 2, namely adapter dimension and probe dimension. Turbidity Sensor works when given a voltage of 5 volts. There are two-pin sockets in the Turbidity Sensor adapter. The socket pin on the right (as shown above) is connected to the probe which is used to detect the turbidity value. While the socket pin on the left (as shown above) is connected to the ground, VCC, and A0 pins on the Arduino Uno. After the turbidity value is known, the probe then transmits data to the Turbidity Sensor adapter which is then sent to Arduino Uno to be processed and processed. 
3. Arduino Uno

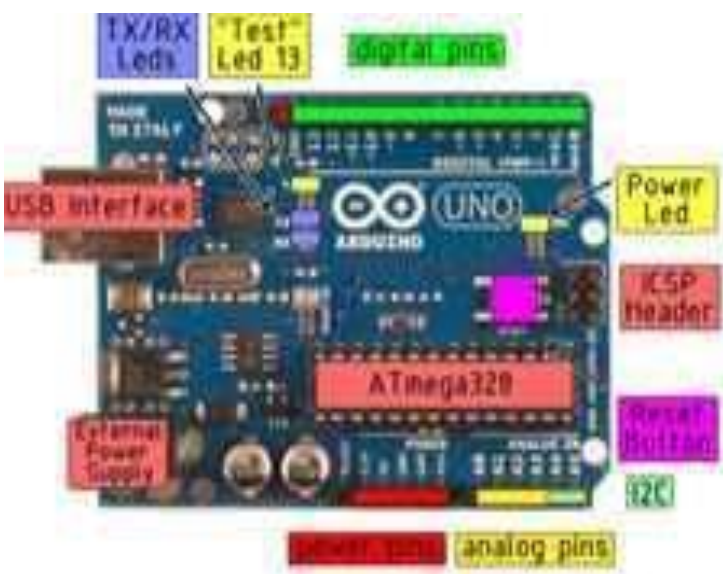

Picture 6 Arduino Uno

Arduino is an open-source single-board microcontroller, Arduino microcontroller hardware is programmed using a wiring-based programming language based on syntax and libraries.(Dinata \& Sunanda, 2015).

Arduino Uno in this tool is used as a controller and processor of the results of the input. Arduino Uno consists of an ATMega 328 microcontroller circuit and has 20 pins. Arduino Uno itself can operate in a voltage of 7-12 volts. In this tool, Arduino UNO functions as a data processor and processor that has been detected by the turbidity sensor. The pins in the Turbidity Sensor are connected to the ground pin, $5 \mathrm{v}$, and the $\mathrm{A} 0$ pin on the Arduino Uno. which then the results that have been processed are displayed by a 16x2 LCD.

\section{Output Circuit}

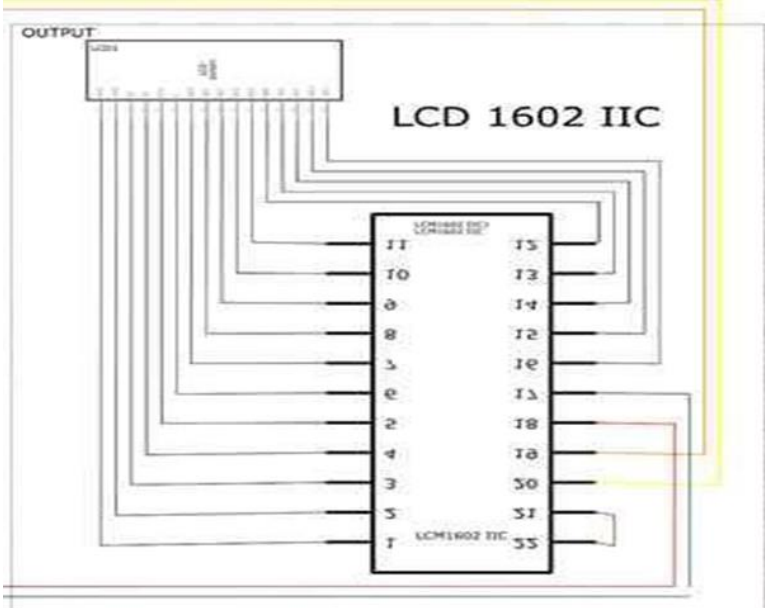

Picture 7 Output Circuit Schematic

LCD is a tool that serves to display size or number so that it can be seen and known through the crystal screen display (Budiyanto, 2012).

When the water turbidity data has been detected by the Turbidity Sensor which is then processed and processed using Arduino Uno, the data in the form of turbidity numbers and water information are then displayed by a $16 \times 2$ LCD. In making this tool the author uses I2C to simplify the pins that will be connected to the Arduino Uno. With the help of I2C, only 4 pins are used, namely ground, VCC, SDA, and SCL.

\section{Flowchart Diagram}

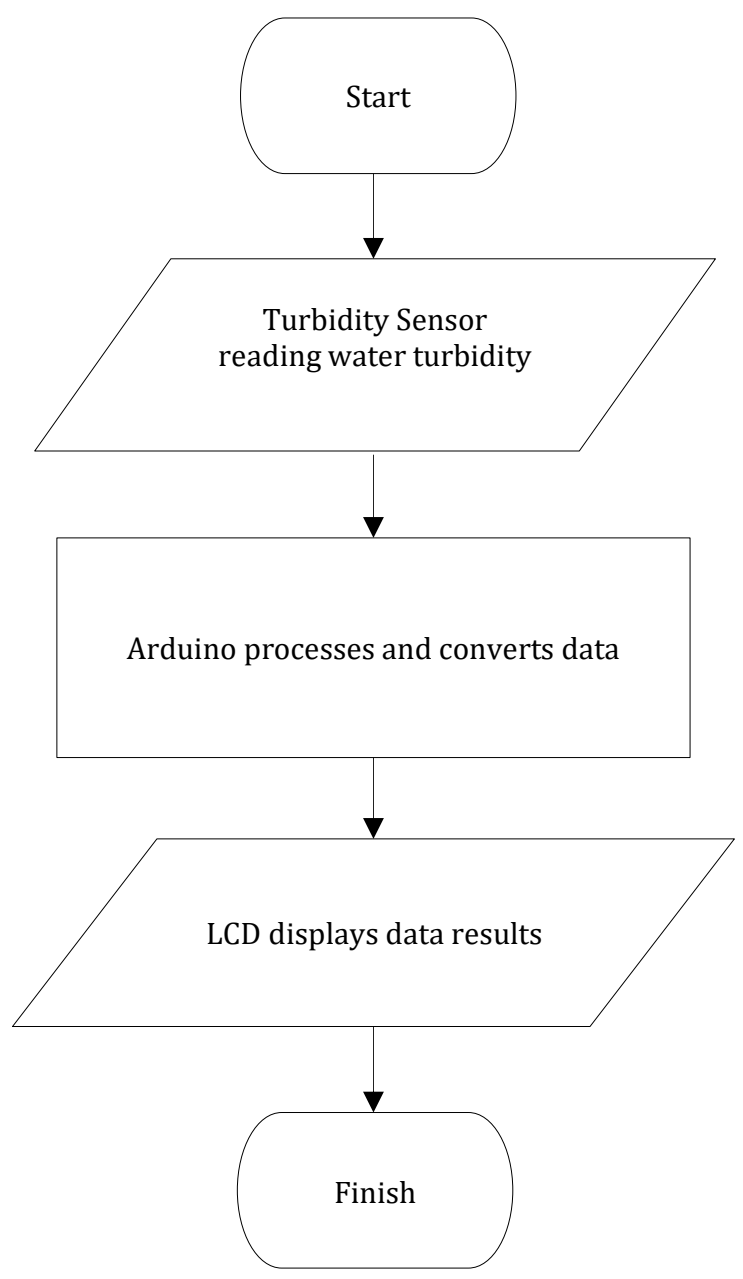

Picture 8 Flowchart Diagram

\section{RESEARCH RESULTS AND DISCUSSION}

In this section, the author will conduct several test schemes, which consist of input experiments, output experiments, and the results of all experiments or conclusions from these experiments. 


\section{A. Input experiment result}

Table 1 The experiment results of input

\begin{tabular}{|c|c|c|c|c|c|c|}
\hline No & Voltage & Water Type & $\begin{array}{l}\text { Turbidity } \\
\text { Sensor }\end{array}$ & $\begin{array}{c}\text { Arduino } \\
\text { Uno }\end{array}$ & NTU & Description \\
\hline \multirow{5}{*}{1} & \multirow{5}{*}{5 Volt } & Mineral Water & True & True & 2,11 & \multirow{5}{*}{$\begin{array}{l}\text { Sensors and } \\
\text { Arduino Uno are } \\
\text { working fine }\end{array}$} \\
\hline & & PAM Water & True & True & 2,40 & \\
\hline & & Well Water & True & True & 3,20 & \\
\hline & & Sand Water & True & True & 11,75 & \\
\hline & & Groundwater & True & True & 3000 & \\
\hline \multirow{5}{*}{2} & \multirow{5}{*}{12 Volt } & Mineral Water & True & True & 2,56 & \multirow{5}{*}{$\begin{array}{l}\text { Sensors and } \\
\text { Arduino Uno are } \\
\text { working fine }\end{array}$} \\
\hline & & PAM Water & True & True & 2,86 & \\
\hline & & Well Water & True & True & 3,35 & \\
\hline & & Sand Water & True & True & 17,57 & \\
\hline & & Ground Water & True & True & 3000 & \\
\hline
\end{tabular}

Table 1, the test results above show that there are several differences in the NTU values of the water tested. The voltage difference between the 5volt Adapter and the 12-volt Adapter is different. The Arduino Uno voltage needed is 7-12 volts, based on previous test results Arduino Uno can still work well with a 5-volt adapter, but the NTU test results are different, with a lower value.

This value is lower because the power supply required by Arduino Uno is less than the

recommended voltage limit. And also do not use a voltage that exceeds the required component (more than 12 volts) because it can damage the component. Therefore, for more accurate results, it is better to use a voltage source that is needed by the Arduino Uno, namely 7 to 12 volts.

\section{B. Experimental results output}

Table 2 Output Result Table

\begin{tabular}{cccccc}
\hline Water Type & $\begin{array}{c}\text { Turbidity } \\
\text { Sensor }\end{array}$ & $\begin{array}{c}\text { Arduino } \\
\text { Uno }\end{array}$ & NTU & LCD & Description \\
\hline Mineral Water & True & True & 2,56 & Clear & Sensors and Arduino Uno are working fine \\
\hline PAM Water & True & True & 2,86 & Clear & Sensors and Arduino Uno are working fine \\
\hline Well Water & True & True & 3,35 & Clear & Sensors and Arduino Uno are working fine \\
\hline Sand Water & True & True & 17,57 & Dirty & Sensors and Arduino Uno are working fine \\
\hline Ground Water & True & True & 3000 & Very Dirty & Sensors and Arduino Uno are working fine \\
\hline
\end{tabular}

From the test results above, the LCD component that is used as an output can work well according to the program that is input.

\section{Overall experiment result}

Table 3 Overall experiment result

\begin{tabular}{|c|c|c|c|c|c|c|c|}
\hline No & Voltase & Water Type & $\begin{array}{c}\text { Turbidity } \\
\text { Sensor }\end{array}$ & $\begin{array}{c}\text { Arduino } \\
\text { Uno }\end{array}$ & NTU & LCD & Description \\
\hline \multirow{5}{*}{1} & \multirow{5}{*}{5 Volt } & Mineral Water & True & True & 2,11 & Cleat & \multirow{5}{*}{ Sensor, Arduino Uno and LCD are working fine } \\
\hline & & PAM Water & True & True & 2,40 & Cleat & \\
\hline & & Well Water & True & True & 3,20 & Cleat & \\
\hline & & Sand Water & True & True & 11,75 & Dirty & \\
\hline & & Ground Water & True & True & 3000 & Very Dirty & \\
\hline \multirow{5}{*}{2} & \multirow{5}{*}{12 Volt } & Air Mineral & True & True & 2,56 & Clear & \multirow{5}{*}{ Sensor, Arduino Uno and LCD are working fine } \\
\hline & & Air PAM & True & True & 2,86 & Clear & \\
\hline & & Well Water & True & True & 3,35 & Clear & \\
\hline & & Sand Water & True & True & 17,57 & Dirty & \\
\hline & & Ground Water & True & True & 3000 & Very Dirty & \\
\hline
\end{tabular}




\section{CONCLUSIONS AND SUGGESTIONS}

\section{Conclusions}

Based on the results of data testing using a water turbidity detector using a Turbidity Sensor with Arduino Uno, the design of this tool consists of an input block, a process block, and an output block. The input block consists of a power supply and a Turbidity Sensor, the process block is carried out by Arduino Uno and the author's output block uses a 16x2 LCD. The level of water turbidity can be detected using the Turbidity Sensor, then the data obtained will be processed and processed by Arduino Uno, which then results in the form of turbidity numbers and water information displayed on a $16 \times 2$ LCD. With a water turbidity detector using a Turbidity Sensor with Arduino Uno, the level of water turbidity can be known more quickly.

\section{Suggestions}

In testing with a water turbidity detector using a turbidity sensor with Arduino Uno, there are still shortcomings. namely in testing this tool to be more thorough in taking data samples so that the data obtained is more accurate, and this tool should be equipped with a voltage source that does not require direct electrical power such as batteries or power banks to facilitate outdoor use.

\section{REFERENCE}

Amani, F., \& Prawiroredjo, K. (2016). ID alat ukur kualitas air minum dengan para. Journal of JETRi, 14, 49-62.

Budiyanto, S. (2012). Sistem Logger Suhu dengan Menggunakan Komunikasi Gelombang Radio. Jurnal Teknologi Elektro, Universitas Mercui Buana, 3 , 21-27. https://doi.org/https://dx.doi.org/10.22441 /jte.v3i1.735

Dinata, I., \& Sunanda, W. (2015). Implementasi Wireless Sensor Network Untukmonitoring Parameterenergi Listrik Sebagaipeningkatan Layananbagi Penyedia Energilistrik. Nasional Teknik Elektro, (1), 83-88.

Effendi, H. (2003). Telaah Kualitas Air Bagi Pengelolaan Sumber Daya dan Lingkungan Perairan. Yoyakarta: Kanisius.

Galih, V., Purnomosari, E., \& N. (2019). Pengantar Pratikum Mekartronika Tekstil. CV. Mulia Jaya.

Joko, T. (2010). Unit Air Baku dalam Sistem Penyediaan Air Minum (Pertama). Yoyakarta: Garaha Ilmu.

Kadir, A. (2013). Panduan Praktis Mempelajari Aplikasi Mikrokontroler dan Pemrogramannya Menggunakan Arduino. Yoyakarta: Andi.
Kautsar, M., Rizal Isnanto, R., \& Didik Widianto, E. (2015). 143285-ID-sistem-monitoringdigital-penggunaan-dan. Teknologi Dan Sistem Komputer, 3(1).

Manaor, A., Efendi, S., \& Informatika, P. T. (2017). Implementasi Pengendalian Lampu Otomatis Berbasis Arduino Menggunakan Metode Fuzzy Logic. Jurnal Penelitian Teknik Informatika Universitas Malikussaleh (TECHSI).

Noor, A., Supriyanto, A., \& Rhomadhona, H. (2019). Aplikasi Pendeteksi Kualitas Air Menggunakan. Corel IT, 5(1), 13-18.

Suliyani, N., Suciyati, S. W., Pauzi, G. A., \& Surtono, A. (2021). Rancang Bangun Alat Ukur Kekeruhan Air Menggunakan Fototransistor dan LED Inframerah Berbasis Arduino Uno. Journal of Energy, Material, and Instrumentation Technology, 2(2), 30-39. https://doi.org/10.23960/jemit.v2i2.53

Suryono, \& Pramusinto, K. (2016). Sistem Monitoring Kekeruhan Air Menggunakan Jaringan Wireless Sensor System Berbasis Web. Youngster Physics Journal, 5(4), 203210.

Sutrino, C. . (2004). Teknologi Penyediaan Air Bersih. Jakarta: Rineka Cipta.

Wadu, R. A., Ada, Y. S. B., \& Panggalo, I. U. (2017). Rancang Bangun Sistem Sirkulasi Air Pada Akuarium/ Bak Ikan Air Tawar Berdasarkan Kekeruhan Air Secara Otomatis. Jurnal Ilmiah FLASH, 3(1), 1-10. Retrieved from http://222.124.191.188/index.php/flash/art icle/view/131\%0Ahttp://222.124.191.188/i ndex.php/flash/article/view/131/74\%0Ahtt p://www.jurnal.pnk.ac.id/index.php/flash/a rticle/view/131

Wardhana, W. A. (2004). Dampak Pecemaran Lingkungan. Yoyakarta: Andi. 